\title{
PEMBERDAYAAN MASYARAKAT YANG MENGALAMI MUSIBAH KEBAKARAN LAHAN DALAM MENINGKATKAN PENDAPATAN KELUARGA DAN MENYELAMATKAN LINGKUNGAN DI DESA CATUR RAHAYU KECAMATAN DENDANG KABUTEN TANJUNG JABUNG TIMUR
}

\author{
Endriani, Yudhi Achnopa, Agus Kurniawan dan Refliaty \\ Dosen Fakultas Pertanian Universitas Jambi \\ email: eend_200662@yahoo.co.id; yudhi_achnopa@yahoo.co.id; \\ aguskurniawan.iwan@gmail.com; refliatyunja@yahoo.co.id
}

\begin{abstract}
ABSTRAK
Kegiatan Pengabdian Kepada Masyarakat ini bertujuan untuk membantu pemulihan ekonomi masyarakat melalui upaya peningkatan pendapatan rumah tangga petani yang terkena dampak kebakaran lahan dan hutan. Kegiatan dilaksanakan di Desa Catur Rahayu Kecamatan Dendang Kabupaten Tanjung Jabung Timur Provinsi Jambi. Pertimbangan utama pemilihan lokasi dan masyarakat adalah di samping merupakan wilayah terkena dampak karlahut 2015 juga merupakan petani kelapa sapi sawit yang sedang menghadapi kegiatan replanting sawit sehingga perlu pengembangan ekonomi alternatif untuk menjadi persiapan bagi rumah tangga dalam menghadapi kehilangan pendapatan sementara (temporary loss income) selama masa replanting sampai kelapa sawit menghasilkan. Metode pelaksanaan adalah : (1) penyuluhan dan pendidikan kepada masyarakat tentang kepedulian terhadap pencegahan kebakaran lahan hutan, (2) pembelajaran masyarakat mengenai replanting pada lahan pasca kebakaran, (3) demplot sebagai percontohan penerapan teknologi yang ditawarkan khususnya dalam upaya revegetasi lahan pasca kebakaran dan terdampak kabut asap. Hasil kegiatan menunjukkan bahwa : (1) Pemberdayaan kelompok tani melalui kegiatan pelatihan dan praktek lapang (demplot) mampu meningkatkan ketrampilan anggota dalam menerapkan teknologi, (2) Introduksi teknologi pengomposan kotoran sapi telah mendorong tumbuhnya usaha pengomposan skala rumah tangga, ditandai dengan telah diadopsinya teknologi pengomposan oleh 9 orang petani. Penguasaan teknologi pengomposan kotoran sapi dapat memicu tumbuhnya usaha agroindustri, khususnya pengomposan di lingkungan kelompok tani Desa Catur Rahayu, (3) Penerapan teknologi biokompos pada usaha tani mentimun dapat mengurangi biaya produksi, meningkatkan hasil tanaman, serta meningkatkan pendapatan dengan $\mathrm{R} / \mathrm{C}$ masing-masing 4,12. Dapat dikatakan bahwa teknologi trichokompos yang diterapkan pada kelompok masyarakat sangat layak untuk dilanjutkan, (4) Berdasarkan observasi yang telah dilakukan, dari keseluruhan petani yang terlibat maka sekitar $70 \%$ petani telah memiliki kemampuan membuat dan mengaplikasikan pupuk organik, (5) Pelatihan pembuatan pupuk organik cair dari limbah ternak dan limbah pertanian. Petani mampu dan terampil membuat pupuk kompos dan POC dari limbah rumah tangga, Petani memiliki pengetahuan tentang berbagai limbah rumah tangga, limbah ternak dan limbah pertanian yang dapat digunakan sebagai bahan pupuk organik, serta berdasarkan observasi yang telah dilakukan, dari keseluruhan petani maka lebih dari $80 \%$ petani telah memiliki kemampuan melakukan pembuatan POC dan kompos dengan benar dari bahan sampah rumah tangga, (5) Sikap positif dan motivasi yang tinggi dari para petani selama mengikuti kegiatan PPM
\end{abstract}

Kata kunci : Kebakaran Lahan Hutan, Replanting, Revegetasi, Teknologi Tepat Guna 


\section{PENDAHULUAN}

\section{Analisis Situasi}

Desa Catur Rahayu terletak di Wilayah Timur Provinsi Jambi, secara Administratif Desa Catur Rahayu berada di Kecamatan Dendang Kabupaten Tanjung Jabung Timur Provinsi Jambi. Desa Catur Rahayu terdiri dari 30 RT dan 4 Dusun yang terbagi berdasarkan Blok dan Jalur yang telah ditentukan. Desa ini memiliki luas wilayah 2.250 ha yang berbatasan langsung dengan : Sebelah Utara: Desa Sido Mukti, Sebelah Selatan : Desa Londrang, Sebelah Barat : Kelurahan Teluk Dawan, Sebelah Timur : Desa Jati Mulyo, dan Desa Kota Kandis Dendang

Orbitasi Desa Catur Rahayu ke Kantor Camat, ibu kota Kabupaten ,Propinsi jambi dan ibu kota Negara Jakarta adalah sebagai berikut : Ke kantor Camat :12,7 km , ke Ibu kota Kabupaten Tanjung Jabung Timur : 14,7 km, ke Ibu kota Propinsi Jambi : 92 km.Kondisi Topografi wilayah daratan Desa Catur Rahayu secara umum berada di dataran rendah yang terdiri dari rawa/gambut yang merupakan dataran rendah berkisar $\pm 0-2$ mdpl ditandai dengan permukaan tanah yang banyak dialiri pasang surut air laut. Desa Catur Rahayu beriklim tropis basah dengan curah hujan rata-rata pertahun berkisar antara $500-1000 \mathrm{~mm}$, suhu udara rata-rata 22 - $30{ }^{\circ} \mathrm{C}$. Pada tahun 1980-2005 Desa Catur Rahayu merupakan lahan Pertanian dan Palawija. Setelah Tahun 2005 sampai sekarang lahan pertanian alih fungsi menjadi perkebunan kelapa sawit. Disamping mengandalkan hasil potensi perkebunan, di sektor pertanian terdapat areal yang dapat dimanfaatkan untuk kawasan tanaman pangan, dengan potensi lahan yang dimiliki oleh Desa Catur Rahayu sampai dengan tahun 2016 seluas 1.650 ha. Sektor ini dapat menjadi potensi unggulan karena masih memungkinkan untuk dikembangkan melalui ekstensifikasi maupun intensifikasi lahan, dengan jenis tanaman Perkebunan Padi dan palawija. Pada tahun 2016 jumlah penduduk Kabupaten Tanjung Jabung Timur terbesar yang tersebar ke 93 Desa/Kelurahan dalam Kabupaten Tanjung Jabung Timur (73 Desa dan 20 Kelurahan) Jumlah Penduduk Desa Catur Rahayu 2.328 dengan jumlah penduduk laki-laki 1.222 jiwa dan penduduk perempuan 1.106 jiwa. Mata pencaharian utama penduduk Desa Catur Rahayu adalahpekebun, petani yang menunjukkan sebagai desa perkebunan dan pertanian. Sebagian besar (94\%) merupakan petani (kelapa sawit) dan $2 \%$ (Pertanian Palawija) sekitar $2 \%$ merupakan pedagang dan usaha lainnya, sedangkan sisanya sekitar $2 \%$ bekerja sebagai pegawai negeri (guru dan pegawai kesehatan), TNI, Polri dan tukang. Kehidupan masyarakat Desa Catur Rahayu terusik dengan timbulnya musibah kebakaran hutan dan lahan yang tidak hanya menyebabkan hutan terbakar bahkan juga lahan tanaman perkebunan dan pangan. Musibah terbesar terjadi pada tahun 2015 yang menyebabkab lebih dari 400 ha lahan kebun dan hutan terbakar. Sedang sisanya mengalami dampak akibat kabut asap yang ditimbulkan.

\section{Permasalahan Mitra}

Motif untuk memperoleh keuntungan ekonomi merupakan penyebab utama terjadinya kebakaranhutan dan lahan. Hal ini termanisfestasikan dalam beberapa cara :(1) Membakar merupakan cara yang paling mudah dan murah dalam kegiatan persiapan lahan.(2) Kegiatan pembalakan kayu meningkatkan kerawanan kebakaran di dalam hutan.(3) Api merupakan 
cara yang paling murah dan efektif yang digunakan dalam konflik sosial terutama masalah konflik kepemilikan lahan antara berbagai pihak terkait.

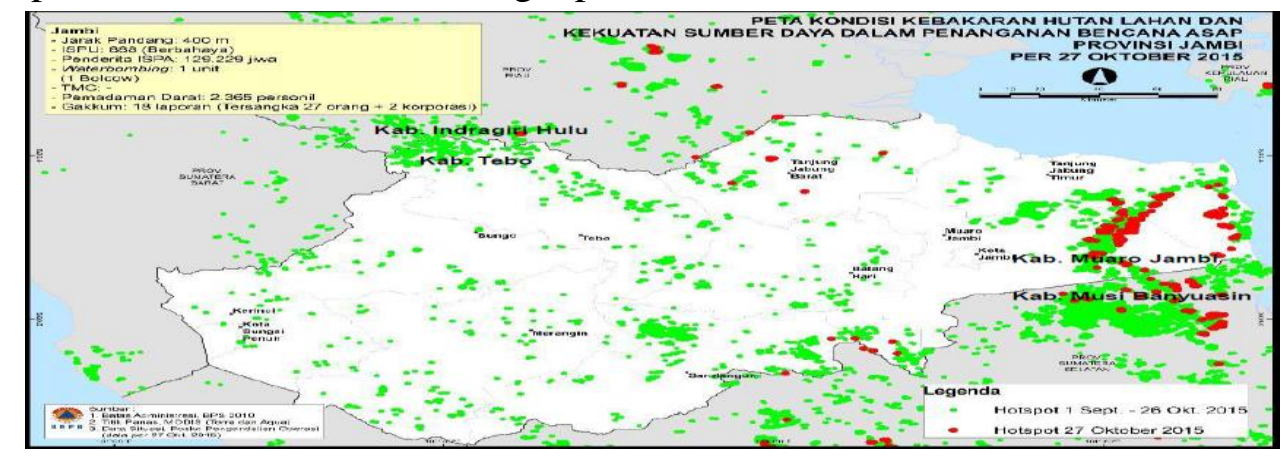

Gambar 1. Kondisi kebakaran lahan dan hutan tahun 2015 di Provinsi Jambi

Kebakaran lahan dan hutan yang terjadi di Provinsi Jambi tahun 2015 merupakan kejadian yang meresahkan masyarakat karena menyebabkan lahan perkebunan dan lahan pangan kehilangan komoditasnya dan petani kehilangan pendapatan. Pantauan BLHD Provinsi Jambi melalui AQMS, Indeks Standar Pencemaran Udara (ISPU) di Jambi berada diangka 730 atau kategori sangat berbahaya. Dampak lain yang dirasakan selama kebakaran lahan dan hutan terjadi, lebih dari satu bulan aktifitas belajar mengajar dihentikan akibat paparan kabut asap. Pada sektor transportasi, jarak pandang terendah selama kabut asap mencapai 200 meter yang menyebabkan lumpuhnya aktifitas penerbangan di Bandara Sultan Thaha Jambi selama lebih dari satu bulan.

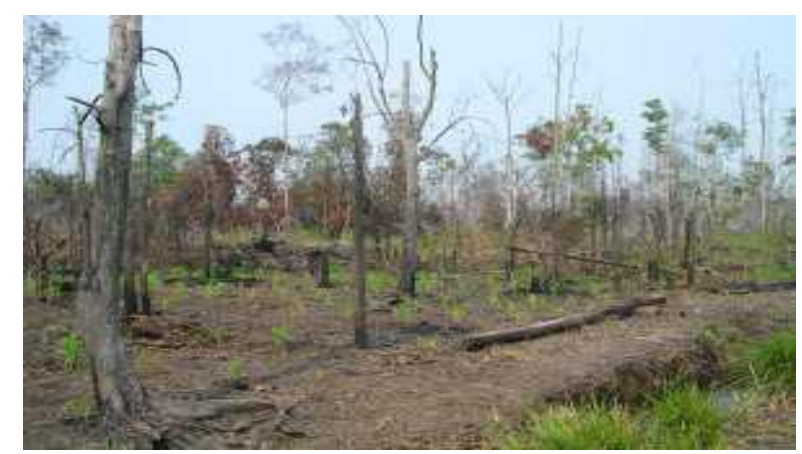

Gambar 2. Hutan gambut bekas terbakar

Beberapa dampak kebakaran lahan dan kabut asap tahun 2015 terhadap sektor pertanian di Provinsi Jambi antara lain 1) Kebakaran lahan gambut berdasarkan data BPBD Provinsi Jambi sekitar 19.528 Ha lahan terbakar 13.459 Ha diantaranya lahan gambut yang tersebar di Kabupaten Muaro jambi, Tanjab Timur dan Tanjab Barat, dan 2) Tanaman tak berbuah seperti kelapa, kelapa sawit, durian di Kumpeh Ulu dan Kumpeh tak berbuah akibat paparan kabut asap, dan adanya kemarau panjang mengakibatkan produktivitas tanaman kelapa sawit menurun drastis. Selain kerugian ekonomi, belum dihitung kerugian akibat terjadinya erosi karena tanah 20 - 30 kali lebih peka dibandingkan dengan daerah hutan yang tidak terbakar, terjadinya percepatanperubahan iklim global, kerugian tidak langsung akibat hilangnya habitat satwa dan erosi berbagaibibit benih tumbuhan dan fauna dilantai hutan, mempercepat penghilangan biomassa lantai hutanmempercepat proses pencucian hara tanah, terjadinya banjir di daerah yang hutan gambutnyaterbakar, dan polusi udara dan air. 


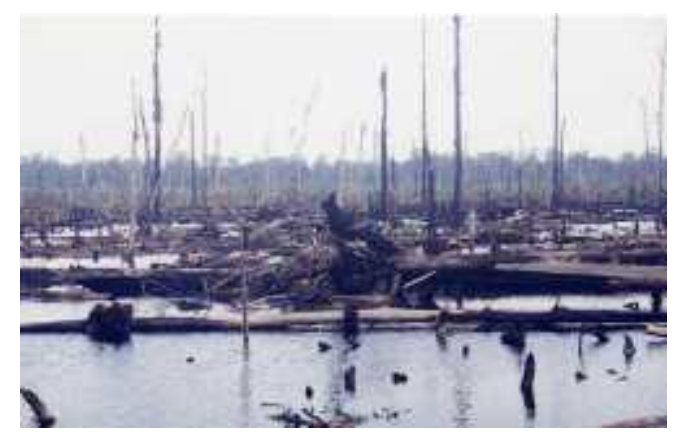

Gambar 3. Areal lahan dan hutan terbuka akibat kebakaran

Kebakaran hutan juga berdampak pada kesuburan tanah. Sifat fisika tanah juga berubah dengan rusaknya struktur tanah sehingga menurunkan infiltrasi dan perkolasi tanah. Hilangnya tumbuhan juga membuat tanah menjadi terbuka sehingga energi pukulan air hujan tidak lagi tertahan oleh tajuk pepohonan. Pada fisik kimia tanah terjadi peningkatan tingkat keasaman tanah dan airsungai. Penelitian yang telah dilakukan menunjukkan terjadinya penurunansifat-sifat retensi kelembaban serta kapasitas kation pada jenis tanah yang mengalami kebakaran.Untuk sifat fisik biologi tanah, kebakaran hutan dapat membunuh organisme tanah yangberyang dapat meningkatkan aerasi dan drainase tanah sedangkan untuk mikroorganisme tanahmisalnya mikorisa yang dapat meningkatkan ketersediaan unsur hara $\mathrm{P}$, $\mathrm{Zn}, \mathrm{Cu}, \mathrm{Mg}$ dan Fe. Kebakaran hutan di Sumatera khususnya di Jambi juga melepaskan jutaan emisi yang terakumulasi diatmosfir. Kawasan gambut yang terbakar menyumbang asap jauh lebih besar (Levine, 1998).Emisi dari lahan gambut yang terbakar mengandung CO dan CO2 dalam jumlah besar sertabeberapa zat-zat tertentu seperti sulfur dan nitrogen dan berbagai jenis campuran yang mudahmenguap (Ward, 1997). Diperkirakan, emisi yang dihasilkan adalah 85 hingga 316 juta karbondioksida, 7 sampai 52 juta karbon monoksida, 4 sampai 16 ton bahan-bahan partikulat, 2 sampai12 juta ton ozon, 0.1 sampai 4 ton amonia dan lebih dari 1.5 juta ton oksida nitrogen.

Sebagian besar kebakaran yang terjadi di hutan gambut tergolong berat mengingat karakteristik gambut itu sendiri yang tersusun dari serasah bahan organic dengan vegetasi di atasnya, dan berpotensi sebagai bahan bakar. Karennanya, pada hutan gambut dikena istilah ground fire, yaitu kebakaran di bawah permukaan yang sangat berdampak buruk terhadap lingkungan. Kebakaran tersebut bisa juga terjadi secara serempak pada bagian bawah maupun atas permukaan gambut, sehingga tidak heran jika setelah kebakaran, vegetasi di atasn permukaan gambut maupun lapisan tanah gambutnya menghilang dan pada musim hujan lokasi ini akan tergenang air yang menyerupai danau. Intervensi manusia sangat diperlukan dalam upaya memperbaiki kondisi lahan hutan yang rusak akibat kebakaran. Upaya perbaikan (restorasi) yang bisa dilakukan adalah melalui rehabilitasi lahan dengan penanaman kembali (replanting). Melalui rehabilitasi diharapkan akan terjadi perbaikan kualitas lahan, yaitu dari areal kosong menjadi areal bervegetasi, atau areal yang miskin vegetasi akan menjadi areal yang kaya akan keanekaragaman hayati. Salah satu bentuk penanganan adalah rehabilitasi yaitu seluruh kegiatan dalam rangka merehabilitasi kawasan bekas dan terdampak akibat kebakaran dengan mempertimbangkan rekomendasi dan/atau masukan berdasarkan data dan informasi yang diperoleh dari hasil identifikasi. Terkait dengan 
dampak kebakaran lahan dan hutan serta paparan asap pada tahun 2015, maka upaya rehabilitasi tidak hanya pada lahan bekas terbakar tetapi juga dibutuhkan pada rehabilitasi tanaman terkena dampak.

\section{Tujuan dan Manfaat Kegiatan}

Secara umum tujuan kegiatan PPM ini adalah mendorong pemanfaatan sumberdaya lokal oleh kelompok masyarakat terkena dampak kebakaran lahan dan hutan dalam meningkatkanpendapatan keluarga secara mandiri dan berkelanjutan. Secara khusus tujuan kegiatan adalah:

a. Meningkatkan produksi pertanian baik secara kualitas dan kuantitas melalui penerapan teknologi revegetasi pasca kebakaran pada masyarakat terkena dampak kebakaran lahan dan hutan (karlahut)

b. Meningkatkan dan mendorong pemanfaatan sumberdaya lokal sebagai sumber pendapatan alternatif bagi rumah tangga terkena dampak karlahut.

c. Memberikan pemahaman dan penyadaran pada masyarakat dalam upaya mencegah karlahut pada lahan usaha tani dan hutan.

d. Mendorong pemanfaatan produk olahan swadaya dalam pemulihan lahan dan tanaman serta ekonomi rumah tangga terkena dampak karlahut

e. Meningkatkan kesadaran dan pengetahuan masyarakat dalam mencegah terjadinya kebakaran lahan dan hutan

Kegiatan diharapkan bermanfaat bagi rumah tangga dan pengambil kebijakan dalam mengembangkan solusi alternatif pemecahan masalah dampak negatif kebakaran lahan dan hutan secara swadaya dan berkelanjutan

\section{Hasil yang diharapkan}

Melalui program Pengabdian Kepada Masyarakat dalam penanggulangan musibah kebakaran lahan dan hutan diharapkan, desa mitra dapat meningkatkan kuantitas, kualitas dan kontinuitas produksi pertanian (khususnya pangan dan perkebunan) sehingga dapat meningkatkan pendapatan rumah tangga masyarakat serta padaa gilirannya memulihkan perekonomian masyarakat. Melalui penyuluhan dan pendidikan dalam upaya revegetasi dan replanting, serta penerapan teknologi revegetasi yang adaptif diharapkan pengetahuan dan kesadaran masyarakat semakin meningkat dan terjadi peningkatan kualitas SDM serta efisiensi waktu dan biaya yang dapat membantu pemulihan ekonomi dan khususnya peningkatan pendapatan keluarga petani yang mengalami musibah kebakaran lahan hutan.

\section{Target Luaran :}

Target luaran dari penerapan PPM ini antara lain adalah :

(1) Bagi pemerintah Kabupaten Tanjung Jabung Timur, akan diperoleh hasil data potensi unggulan daerah dan potensi pengembangan usaha di wilayah Desa Catur Rahayu Kecamatan Dendang. Diharapkan program kegiatan ini dapat meningkatkan pendapatan petani, memberikan ketrampilan dalam pemanfaatan teknologi tepat guna pola usaha rehabilitasi lahan bekas kebakaran lahan hutan, meningkatkan dan 
menghasilkan wirausaha baru melalui diversivikasi tanaman ,yang didukung oleh peningkatan pemahaman masyarakat akan urgensi produk unggulan daerah.

(2) Bagi pihak Universitas Jambi, program Penerapan PPM ini diharapkan akan meningkatkan jalinan kerjasama kelembagaan antara Universitas Jambi dengan Pemerintah Daerah Kabupaten Tanjung Jabung Timur dengan memanfaatkan kepakaran dari Perguruan Tinggi tersebut.

(3) Kegiatan PPM ini sebagai bentuk kepedulian Universitas Jambi terhadap upaya pencegahan dan penanggulangan kebakaran lahan dan hutan dan upaya mitigasi pencemaran lingkungan. Juga sebagai bentuk partisipasi Universitas Jambi dalam mendukung program pemerintah Provinsi Jambi dalam mencegah dan menanggulangi dampak kebakaran lahan dan hutan.

\section{METODE PELAKSANAAN}

\section{Waktu dan Tempat}

Kegiatan pengabdian kepada masyarakat ini dilaksanakan selama 6 (enam) bulan pada tahun 2017, yaitu bulan Juni s.d November 2017. Tempat yang dipilih adalah wilayah yang mengalami musibah keakaran lahan hutan, yaitu Desa Catur Rahayu pada koordinat S $1^{\circ} 14^{\text {' }}$ 22.0092” , E $103^{\circ}$ 53' 1.824” Kecamatan Dendang Kabupaten Tanjung Jabung Timur (Gambar 4).

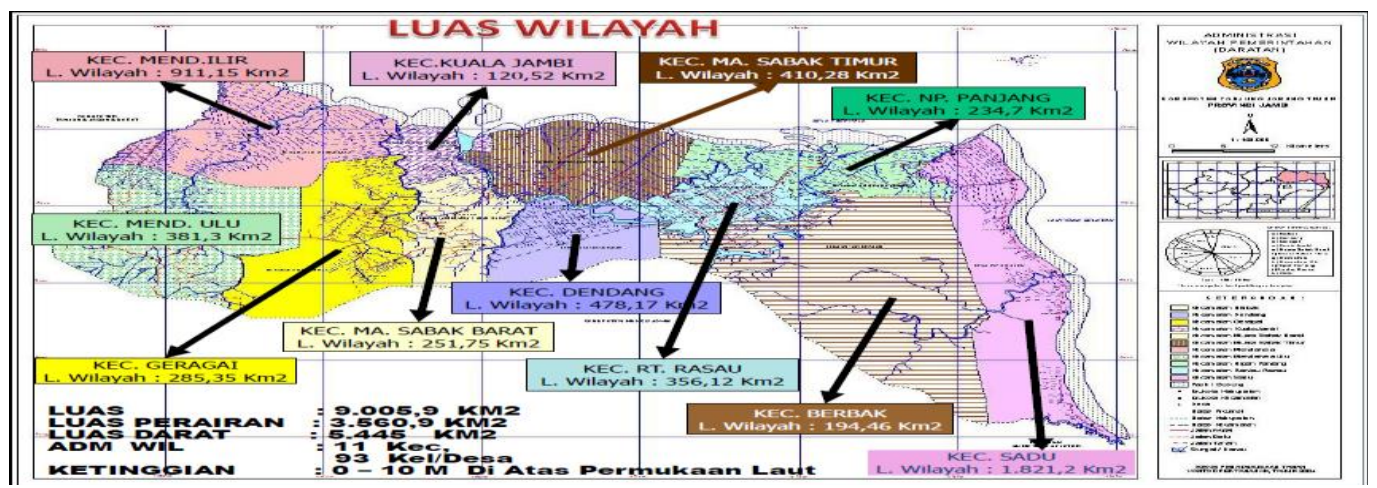

Gambar 4. Peta wilayah tempat kegiatan PPM

\section{Metode Kegiatan}

Kegiatan pengabdian kepada masyarakat ya g mengalami musibah kebakaran hutan dan lahan ini adalah sebagai berikut :

1. Memberikn penyuluhan dan penyadaran kepada masyarakat Desa Catur Rahayu agar membuka dan mengelola lahan dengan cara tanpa bakar,

2. Memberikan pelatihan kepada masyarakat tentang berbagai jenis alternatif kegiatan pada lahan gambut yang mampu meminimalkan dampak negatif dari kegiatan terhadap keberdaan lahan gambut

3. Melibatkan masyarakat dalam mengambil keputusan tentang pengelolaan lahan gambut 
4. Memberikan pendidikan kepada masyarakat dalam mengendalikan sistem drainase di lahan gambut dan memperbaiki serta mempertahankan tinggi muka air di dalam lahan gambut dan sekitarnya

5. Memberikan pemahaman kepada masyarakat agar mengelola lahn gambut dengan menggunakan pendekatan DAS (daerah aliran sungai)

6. Menmbuat demplot-demplot yang menggambarkan pengelolaan lahan gambut berkelanjutan dan dapat memulihkan pendapatan keluarga petani. (proyek percontohan)
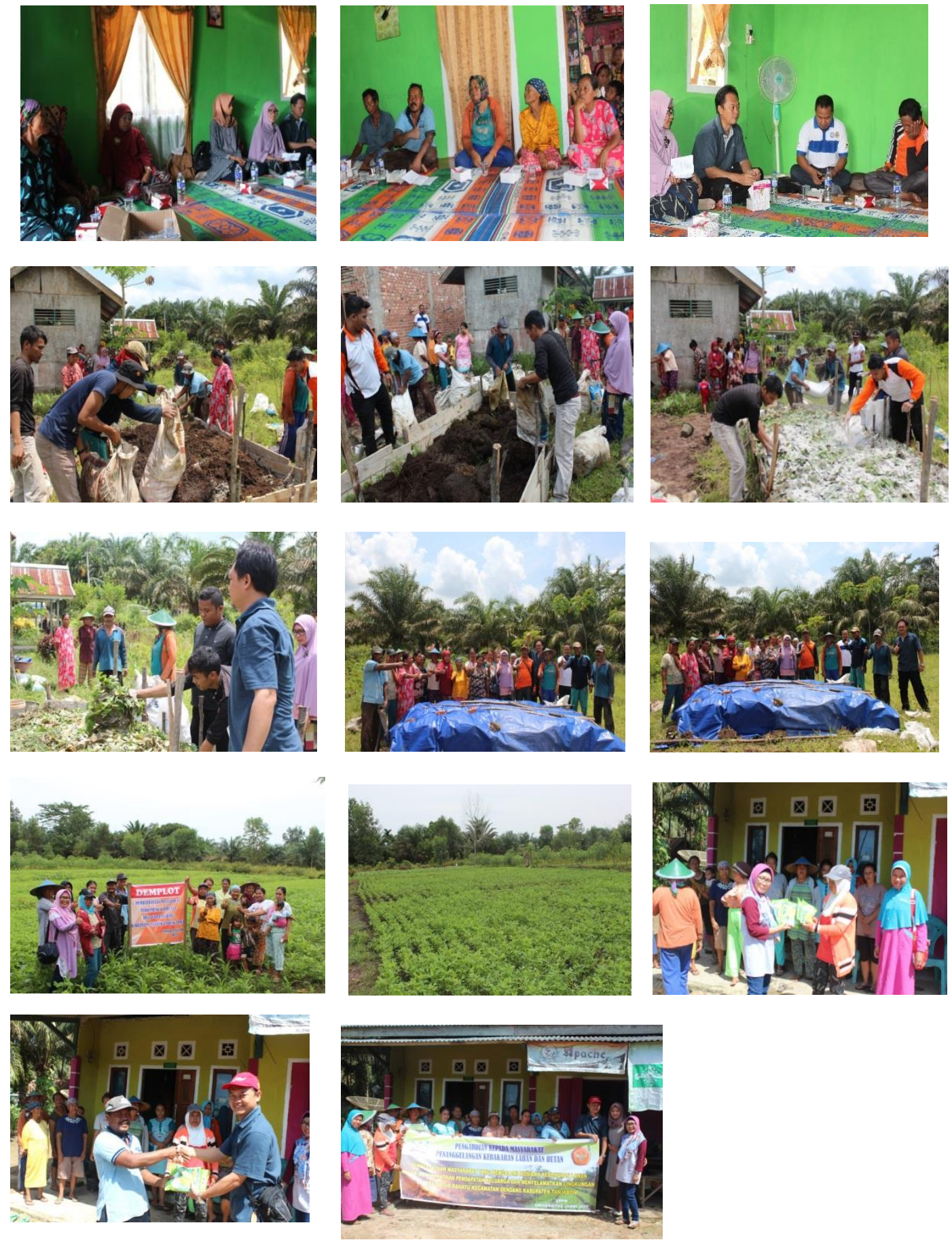

Gambar 5. Aktivitas kegiatan penyuluhan, pelatihan dan introdusir teknologi kompos 
Usaha-usaha yang akan dilakukan guna mencapai tujuan/sasaran PPM di Desa Catur Rahayu adalah :

1. Melaksanakan sosialisasi program PPM pada masyarakat Desa Catur Rahayu.

2. Melaksanakanpenyuluhan dan pendidikan pada masyarakat tentangupaya pengelolaan lahan pertanian pada lahan gambut tanpa bakar, ramah lingkungan dan berkelanjutan

3. Melaksanakan kursus tentang pertanian pada lahan gambut bekas kebakaran

4. Melaksanakan penyuluhan tentang upaya pengelolaan lahan gambut berbasis DAS

5. Melaksanakan pelatihanpembuatan kompos dari bahan lokal dan dengan bioaktivator untuk mengoptimalkan kehidupan organisme pada lahan bekas terbakar.

6. Melaksanakan demplot atau percontohan pelaksanaan replanting pada lahan bekas terbakar

7. Melaksanakan evaluasi pelaksanaan program PPM pada masyarakat Desa Catur Rahayu, dengan cara pertemuan dengan anggota kelompok tani baik di lapangan maupun di ruangan, serta mendiskusikan perkembangan di lapangan.

8. Melaksanakan pelatihan manajemen produksi dan manajemen pemasaran

9. Melakukan evaluasi keberhasilan program, dengan indikator partisipasi masyarakat dan hasil usaha tani demplot.
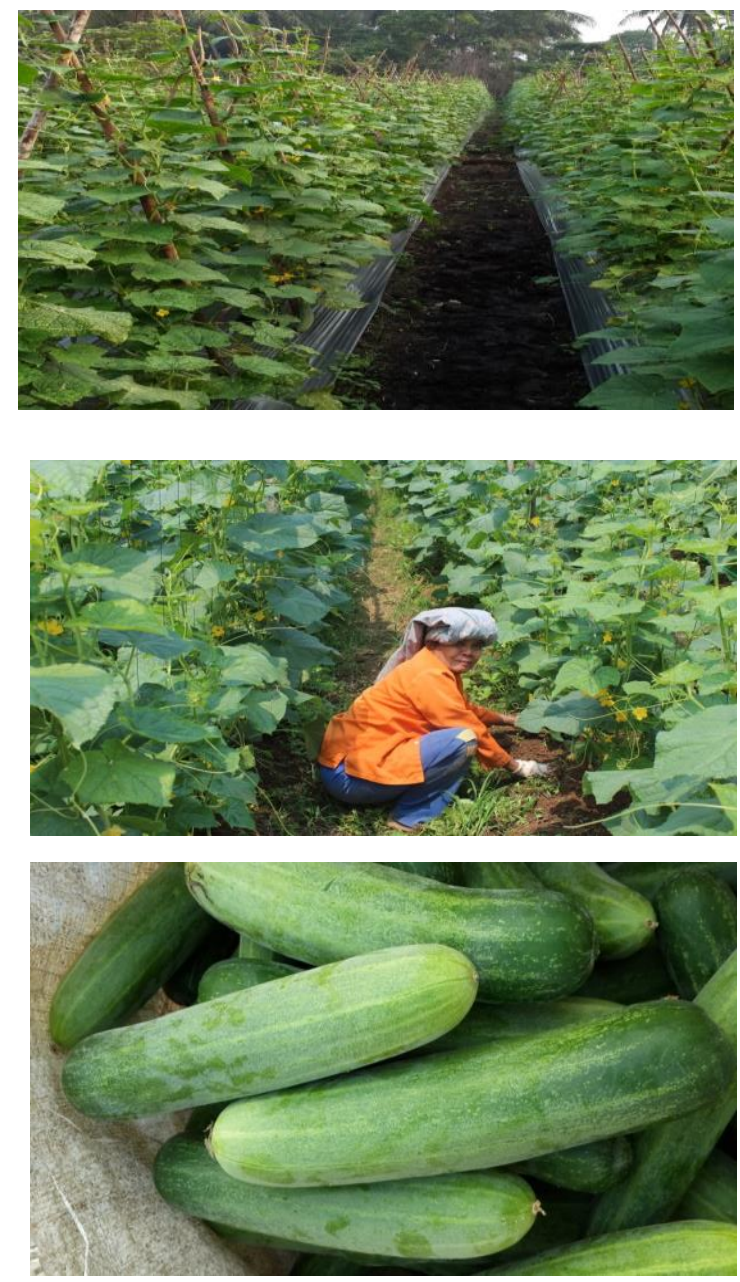

Gambar 6. Salah satu hasil demplot tanaman
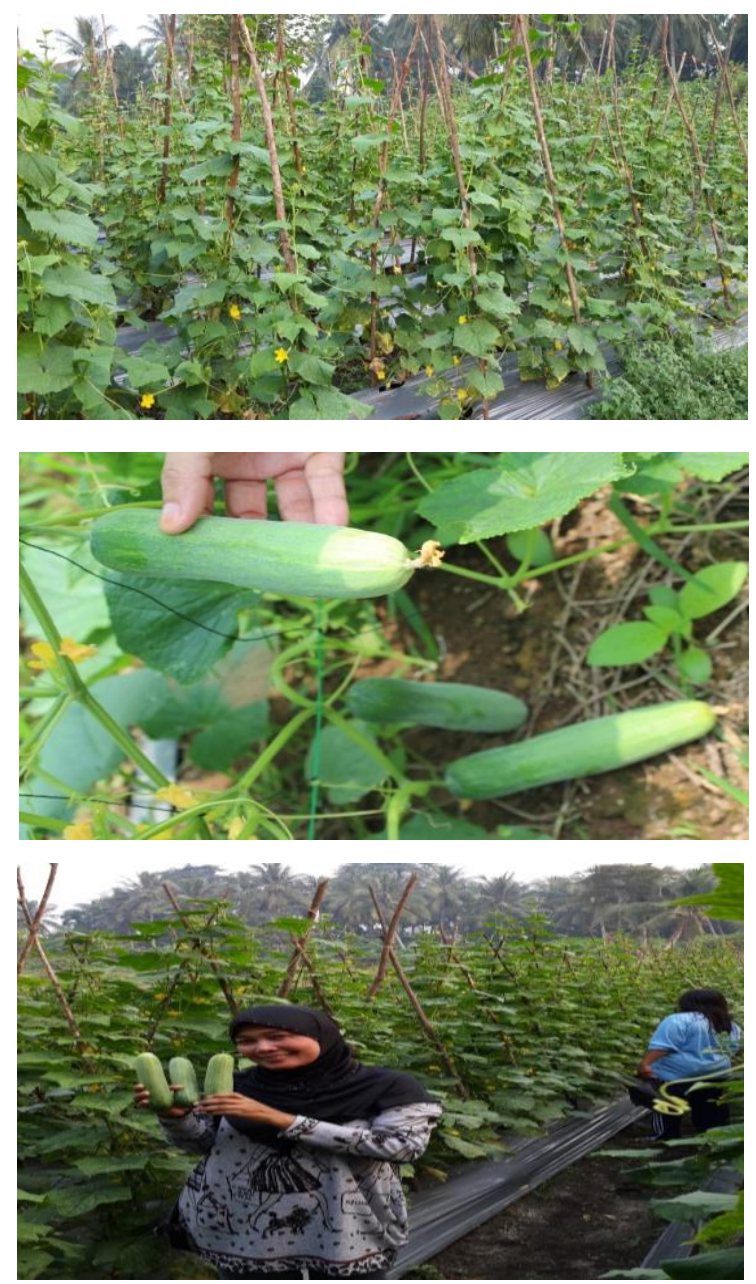


\section{HASIL DAN PEMBAHASAN}

\section{Deskripsi lokasi}

Desa Catur Rahayu dahulunya adalah eks Pemukiman Transmigrasi yang bernama Dendang II UPT IV penempatan tahun 1980/1982 yang pada awalnya berjumlah 733 kepala keluarga yang terdiri dari 2273 jiwa. Para Transmigran sebagian besar adalah penduduk yang berasal dari pulau Jawa ( Sunda, Jawa, Bugis dan Melayu ). Desa Catur Rahayu merupakan daerah aliran sungai pasang-surut dengan ketinggian $0-2$ mdpl. Mata pencaharian penduduknya bertani kebun sawit dan bersawah tanaman pangan berupa padi yang hanya bisa dipanen 1 tahun sekali.

Desa Catur Rahayu terletak di Wilayah Timur Provinsi Jambi,Secara Administratif Desa Catur Rahayu berada di Kecamatan Dendang Kabupaten Tanjung Jabung Timur Provinsi Jambi. Desa Catur Rahayu terdiri dari 30 RT dan 4 Dusun yang terbagi berdasarkan Blok dan Jalur yang telah ditentukan. Desa ini memiliki luas wilayah 2.250 ha.

Kondisi tofograpi wilayah daratan Desa Catur Rahayu secara umum berada di dataran rendah yang terdiri dari rawa/gambut yang merupakan dataran rendah berkisar $\pm 0-2$ mdpl ditandai dengan permukaan tanah yang banyak dialiri pasang surut air laut. Desa Catur Rahayu beriklim tropis basah dengan curah hujan rata-rata pertahun berkisar antara $500-1000$ mililiter, suhu udara rata-rata $22-30{ }^{\circ} \mathrm{C}$. Disamping mengandalkan hasil potensi perkebunan, disektor pertanian terdapat areal yang dapat dimanfaatkan untuk kawasan tanaman pangan, dengan potensi lahan yang dimiliki oleh Desa Catur Rahayu sampai dengan tahun 2016 seluas 1.650 ha. Sektor ini dapat menjadi potensi unggulan karena masih memungkinkan untuk dikembangkan melalui ekstensifikasi maupun intensifikasi lahan, dengan jenis tanaman perkebunan padi dan palawija.

Mata pencaharian utama penduduk Desa Catur Rahayu adalah pekebun, petani yang menunjukkan sebagai desa perkebunan dan pertanian. Sebagian besar (94\%) merupakan petani (kelapa sawit) dan $2 \%$ (pertanian palawija) sekitar $2 \%$ merupakan Pedagang dan Usaha Lainnya, sedangkan sisanya sekitar $2 \%$ bekerja sebagai pegawai negeri (guru dan pegawai kesehatan), TNI, Polri dan tukang. Aksesibilitas terhadap desa sampai saat ini masih sangat luas yang dapat dijangkau dengan kendaraan air, kendaraan roda dua (sepeda motor), dan mobil . Perjalanan dari Kota Jambi memakan waktu lebih kurang 3 Jam (darat).Aksesibilitas terhadap desa sampai saat ini masih sangat luas yang dapat dijangkau dengan kendaraan air, kendaraan roda dua (sepeda motor), dan mobil . Perjalanan dari Kota Jambi memakan waktu lebih kurang 3 Jam (darat).

\section{Pelatihan Pembuatan Biokompos Berbasis Kotoran Sapi, Pupuk Organik Cair dan Biopestisida}

Hasil studi karakteristik pada awal kegiatan menunjukkan bahwa petani mempunyai keterbatasan dalam penguasaan teknologi. Di sisi lain, penyuluh setempat menyatakan bahwa perkembangan teknologi yang cepat menyebabkan petani ketinggalan dalam teknologi. Agar percepatan technologi yang berkembang dapat diserap masyarakat Desa Catur Rahayu, maka telah dilakukan Ipteks bagi Masyarakat berupa introduksi teknologi yang dibutuhkan petani. Pada tahap awal, dilakukan sosialisasi, dengan tujuan untuk memperkenalkan teknologi yang akan dikaji dan menentukan jadwal kegiatan selanjutnya. 
Dalam rangka memberikan bekal bagi petani dalam menerapkan teknologi pengomposan dalam memproduksi trichokompos dilaksanakan pelatihan. Kegiatan pelatihan terdiri dari 2 macam : yakni penyuluhan teori yang disampaikan di rumah ketua kelompok tani dan dilanjutkan dengan praktek lapang untuk pembuatan trichokompos. Pelatihan dihadiri 40 orang terdiri anggota kelompok tani,pemuda karang taruna, dan anggota gapoktan Desa Catur Rahayu, penyuluh pertanian setempat, aparat desa dan kecamatan.

Selama pengabdian berlangsung telah dilakukan 3 tahap pengomposan, dimana masingmasing sejumlah 1 rit (sekitar 3 ton). Proses pengomposan dilakukan secara kolektif oleh anggota kelompok. Proses pengomposan membutuhkan waktu 25 hari, dan menghasilkan kompos dengan visual baik, yaitu remah dan tidak lengket. Selama proses pengomposan dilakukan petani didampingi untuk melakukan pengamatan terhadap kadar air dan suhu.

Untuk menguji bahwa proses pengomposan mampu meningkatkan kualitas kotoran ternak maka dilakukan analisis laboratorium terhadap kotoran ayam segar dan trichokompos kotoran ayam, dimana hasilnya seperti terlihat pada Tabel 1. Berdasarkan uji laboratorium terhadap komposisi kimiawi kompos dapat disimpulkan bahwa petani mampu menguasai teknologi pengomposan kotoran ayam dengan baik. Dari $\pm 3.000 \mathrm{~kg}$ bahan baku pembuatan kompos diperoleh kompos jadi sebanyak $2.000 \mathrm{~kg}$, dan dengan total biaya Rp. 2.200.000 maka harga pokok kompos Rp.1.100,-/kg (Tabel 2). Berdasarkan pengamatan, harga jual kompos yang beredar di pasaran berkisar Rp. 400-Rp.450/kg.

Tabel 1. Kandungan Hara Biokompos Kotoran Sapi Kelompok Tani Desa Catur Rahayu 2017.

\begin{tabular}{cccc}
\hline No. & Kandungan & Kotoran ayam segar & $\begin{array}{c}\text { Trichokompos kotoran } \\
\text { ayam }\end{array}$ \\
\hline 1. & Total N & $0,7 \%$ & $2,58 \%$ \\
2. & $\mathrm{P}_{2} \mathrm{O}_{5}$ & $0,5 \%$ & $2,52 \%$ \\
3. & $\mathrm{~K}_{2} \mathrm{O}$ & $0,4 \%$ & $1,90 \%$ \\
4. & $\mathrm{CaO}$ & - & $2,88 \%$ \\
5. & $\mathrm{MgO}$ & - & $0,76 \%$ \\
6. & $\mathrm{C} / \mathrm{N}$ & $25-30$ & 14 \\
7. & $\mathrm{pH}$ & 8,8 & $6,5-7,5$ \\
8. & Kadar air & $85 \%$ & $35 \%$ \\
\hline
\end{tabular}

Introduksi teknologi pengomposan kotoran sapi telah mendorong tumbuhnya usaha pengomposan skala rumah tangga, ditandai dengan telah diadopsinya teknologi pengomposan oleh 9 orang petani. Petani tersebut melakukan pengomposan secara individu dengan trichoderma sebagai biodekomposer yang dibeli dari kelompok. Skala pengolahan berkisar $500 \mathrm{~kg}-1.000 \mathrm{~kg} /$ petani. Alasan yang disampaikan petani, pengangkutan yang selama ini menjadi masalah dapat diatasi.

\section{Teknologi Pemanfaatan Trichokompos pada Usaha Tani Mentimun}

Mentimun (Cucumis Sativus L) merupakan sayuran buah yang memiliki kandungan mineral dan vitamin cukup tinggi. Disamping untuk memenuhi kebutuhan pasar sebagai konsumsi untuk sayur, mentimun dapat dijadikan berbagai keperluan seperti obat penurun panas, mengurangi sakit tenggorokan dan batuk, serta sebagai bahan baku kosmetik 
(pembersih wajah dan lulur). Ada 4 varietas mentimun yang dapat dibudidayakan dengan produksi cukup tinggi, yaitu Venus, Asian Star, Sabana dan Krakatau dengan potensil hasil 25 sampai 29 ton/ha (pada musim kemarau) dan 13 sampai 18 ton/ha (pada musim hujan).

Tabel 3. Biaya produksi dan keuntungan menggunakan teknologi tradisional dan teknologi trichokompos pada usaha tani mentimun di lahan kering DesaCatur Rahayu Kecamatan Dendang Kabupaten Tanjabtim

\begin{tabular}{lrr}
\hline \multicolumn{1}{c}{ Uraian } & Teknologi Tradisional & Teknologi Pupuk Hijau \\
\hline Tenaga kerja HOK & 2.145 .000 & 2.145 .000 \\
Sarana produksi (Rp/ha) & 2.850 .000 & 3.200 .000 \\
Total biaya Produksi: & 4.995 .000 & 5.345 .000 \\
Fisik (kg/ha) & 14500 & 26000 \\
Nilai (Rp/ha) & 13.150 .000 & 22.000 .00 \\
Keuntungan (Rp/ha) & 7.100 .000 & 0 \\
Rasio R/C & 2,63 & 16.655 .00 \\
& & 0 \\
\end{tabular}

Penanaman mentimun untuk musim kemarau dilakukan sekitar bulan Juli atau bulan September. Pengolahan tanah dengan menggunakan cangkul dengan membuat bedengan ukuran lebar 80 - 90 dan tinggi $30 \mathrm{~cm}$. yang sekaligus membuat saluran lebar \pm 70 $\mathrm{cm}$. Pupuk trichokompos dari kotoran sapi yang sudah matang diberikan dengan takaran $2.000 \mathrm{~kg} / \mathrm{ha}$ yang diberikan pada lubang untuk tempat penanaman biji dengan jarak $60 \mathrm{x} 40$ $\mathrm{cm}$. Penanaman dilakukan dengan cara tugal dengan jumlah benih 2-3 biji per lubang. Pupuk buatan (an organik) terdiri dari NPK (Phonska) Urea/ZA, SP-36, KCI dan pupuk daun masing-masing per hektar dibutuhkan 75,50, $25 \mathrm{~kg}$ (setengah dosis). Pemberian pupuk buatan dapat dilakukan dengan cara, yaitu pupuk diberikan pada tugalan/larik di sekitar $5-10 \mathrm{~cm}$ jarak dari tanaman sebanyak 3 tahap pemberian Panen buah mentimun muda lokal untuk sayuran, asinan atau acar umumnya dipetik 2-3 bulan setelah tanam, mentimun hibrida dipanen 42 hari setelah tanam Mentimun dipanen setelah matang. Buah dipanen di pagi hari sebelum jam 9.00 dengan cara memotong tangkai buah dengan pisau tajam.Mentimun sayur dipanen 5 - 10 hari sekali tergantung dari varitas dan ukuran/umur buah yang dikehendaki.

Secara ekonomis, usaha budidaya mentimun di lahan kering pada musim kemarau (dengan pengairan terjamin) dapat memberikan keuntungan tiap hektarnya cukup tinggi, yaitu Rp16.655.000,- (R/C 4,12) dengan biaya produksi Rp.5.345.500. Sementara itu, pada usaha tani tradisionil memberikan keuntungan Rp.7.100.000,- (R/C 2,63) dengan biaya produksi Rp.4.995.500,- (Tabel 3).

\section{KESIMPULAN DAN SARAN}

Berdasarkan observasi dan hasil kegiatan yang telah dilaksanakan dapat disimpulkan bahwa:

1. Pemberdayaan kelompok tani melalui kegiatan pelatihan dan praktek lapang (demplot) mampu meningkatkan ketrampilan anggota dalam menerapkan teknologi. Sedangkan 
upaya mediasi yang dilakukan dengan pihak swasta, dapat menjamin ketersediaan sarana produksi yang dibutuhkan kelompok tani.

2. Introduksi teknologi pengomposan kotoran sapi telah mendorong tumbuhnya usaha pengomposan skala rumah tangga, ditandai dengan telah diadopsinya teknologi pengomposan oleh 9 orang petani. Penguasaan teknologi pengomposan kotoran sapi dapat memicu tumbuhnya usaha agroindustri, khususnya pengomposan di lingkungan kelompok tani Desa Catur Rahayu.

3. Penerapan teknonologi biokompos pada usaha tani mentimun dapat mengurangi biaya produksi, meningkatkan hasil tanaman, serta meningkatkan pendapatan dengan R/C masing-masing 4,12. Dapat dikatakan bahwa teknologi trichokompos yang diterapkan pada kelompok masyarakat sangat layak untuk dilanjutkan.

4. Berdasarkan observasi yang telah dilakukan, dari keseluruhan petani yang terlibat maka sekitar $70 \%$ petani telah memiliki kemampuan membuat dan mengaplikasikan pupuk organik.

5. Pelatihan pembuatan pupuk organik cair POC dari limbah ternak dan limbah pertanian.Petani mampu dan terampil membuat pupuk kompos dan POC dari limbah rumah tangga, Petani memiliki pengetahuan tentang berbagai limbah rumah tangga limbah ternak dan limbah pertanian yang dapat digunakan sebagai bahan pupuk organik serta berdasarkan observasi yang telah dilakukan, dari keseluruhan petani maka $>80 \%$ petani telah memiliki kemampuan melakukan pembuatan POC dan kompos dengan benar dari bahan sampah rumah tangga.

5. Sikap positif dan motivasi yang tinggi dari para petani selama mengikuti kegiatan PPM. Ini ditunjukkan kehadiran dan minat para petani pada setiap diskusi dan pelatihan.

\section{UCAPAN TERIMAKASIH}

Terima kasih disampaikan kepada Bapak Rektor Universitas Jambi yang telah mendanai kegiatan PPM ini melalui Dana PNBP LPPM, dan terima kasih kepada Ibu Ketua LPPM yang sudah menyetujui dilaksanakannya kegiatan PPM. Terima kasih juga kepada Bapak dekan Fakultas Pertanian UNJA yang sudah memfasilitasi hingga kegiatan PPM ini dapat terlaksana dengan baik. Terima juga disampai kepada Kepala Desa Catur Rahayu yang sudah menerima kami dengan baik sekali.

\section{DAFTAR PUSTAKA}

Arinal, I dan INN. Suryadinata.2004. Kegiatan Penanaman Kembali (Rehabilitasi) Berbagai Jenis Tanaman Kehutanan pada Lahan Gambut Bekas Terbakar di Dalam Kawasan Taman Nasional Berbak-Jambi. CCFPI. Wetlands International - Indonesia Programme. Jambi. Indonesia.

Tacconi, L. 2003. Kebkaran Hutan di Indonesia: Penyebab, biaya dan implikasi kebijakan. CIFOR. Bogor . Indonesia.

Komisi Daerah REDD Provinsi Jambi. 2012. Dokumen Risalah Eksekutif Strategi dan Rencana REDD Provinsi Jambi 2012 -2030. Komisi Daerah REDD Provinsi Jambi Tricahyo, I, Wibisono, Labueni, s dan INN Syuryadiputra. 2004. Rehabilitasi Hutan/Lahan Rawa Gambut Bekas Terbakar. Wetlands Internationals Indonesia Programme. 